\title{
Cochlear Implantation in a Case of Auditory Neuropathy Spectrum Disorder with CAPOS Syndrome
}

\section{CAPOS Sendromu ve İsitsel Nöropati Spektrum Bozukluğu Olan Bir Hastada Koklear Implantasyon}

\section{Atılım ATILGAN ๑, Mustafa YUKSEL $\odot$, Ayca CIPRUT $\odot$}

Ethics Committee Aproval: Not Applicable.

Confillict of Interest: The authors declare that they have no conflict of interest.

Funding: None.

Informed Concent: Informed consent was taken.
Cite as: Atilgan A, Yuksel M, Ciprut A. Cochlear implantation in a case of auditory neuropathy spectrum disorder with CAPOS syndrome. Medeniyet Med J. 2019;34:318-23.

\begin{abstract}
Auditory neuropathy spectrum disorder (ANSD) is a hearing disorder which characterized with normal outer hair cell function but disrupted neural synchrony in the afferent auditory pathway. CAPOS (cerebellar ataxia, areflexia, pes cavus, optic atrophy, and sensorineural hearing loss) syndrome can manifest itself with ANSD and this rare situation and audiological rehabilitation outcomes have not well documented in the literature. We aim to present a cochlear implant user subject with CAPOS syndrome and ANSD. A 14-year-old girl diagnosed with ANSD and CAPOS syndrome. She received unilateral cochlear implant (CI). Her hearing sensitivity and speech perception abilities have been improved with $\mathrm{Cl}$. Also, she has a good music perception ability measured with the Turkish version of Clinical Assessment of Music Perception Test. After detailed audiological evaluations, Cl could be a good option for patients who have ANSD and CAPOS syndrome.
\end{abstract}

Keywords: Cochlear implant, auditory neuropathy spectrum disorder, CAPOS syndrome

öz

İşitsel Nöropati Spektrum Bozukluğu (INSB) normal dış tüy hücre fonksiyonuna ragmen afferent işitsel yollarda senkronizasyonun kesintiye uğramasıyla tanımlanan bir işitme problemidir. Birçok gen mutasyonu iNSB'ye neden olabilir ve bazı vakalarda ek patolojiler gözlenebilir. CAPOS (serebellar ataksi, arefleksi, pes kavus, optik atrofi ve sensorinöral ișitme kaybı) sendromunda sensorinöral işitme kaybı INSB ile kendini gösterir ve odyolojik rehabilitasyonla ilgili sonuçlar literatürde yeterince açıklanmamıştır. Bu çalışmada CAPOS sendromu ve INSB'si olan koklear implant kullanıcısı bir hasta sunulmuştur. 14 yaşında kız hasta INSB ve CAPOS sendromuyla tanılanmıştır. Bir yıl süren takibin ardından unilateral koklear implant kullanmaya başlamıştır. Koklear implant sonrasında hastanın işitme eşiklerinde ve konuşmayı algılama performansında belirgin derecede iyileşme gözlenmiștir. Ayrıca Müzik Algısının Klinik Değerlendirmesi Testinin Türkçe versiyonunda müzik algısı performasının yüksek olduğu görülmüştür. Detaylı odyolojik değerlendirmeler sonrasında CAPOS sendromu ve INSB'si olan hastalar için koklear implant iyi bir seçenek olabilir.

Anahtar kelimeler: Koklear implant, işitsel nöropati spektrum bozukluğu, CAPOS sendromu
Received: 29 July 2019

Accepted: 14 August 2019

Online First: 27 September 2019

Corresponding Author: A. Atilgan

ORCID: 0000-0003-2944-6404

Marmara University, Department of Audiology, Istanbul, Turkey

atilimatilgan@gmail.com

M. Yuksel

ORCID: 0000-0002-9092-7541

A. Ciprut

ORCID: 0000-0002-0295-8760

Marmara University, Department of Audiology, İstanbul, Turkey 


\section{INTRODUCTION}

Auditory neuropathy spectrum disorder (ANSD) is a hearing disorder that can be diagnosed by an absent or abnormal auditory brainstem responses (ABR) and presence of outer hair cell function. The most prominent indication of the outer hair cell function is a clear cochlear microphonic in an ABR waveform with an absent or abnormal ABR response and the presence of otoacoustic emissions $(\mathrm{OAEs})^{1}$.

The behavioral pure-tone thresholds (BPTT) of patients with ANSD vary greatly. In most cases, hearing thresholds fluctuate and are unstable. These symptoms often correlate with poor speech perception abilities, especially in the presence of background noise ${ }^{2}$. Sound localization abilities are also deteriorated ${ }^{3}$.

Disrupted neural synchrony despite normal peripheral activity can be caused by presynaptic dysfunction of the inner hair cells, this disrupted neural synchrony can occur in pre-, and postsynaptic nerve terminal synapses within the inner hair cells, and postsynaptic unmyelinated and myelinated dendrites, auditory ganglion cells and myelinated axons ${ }^{4}$. The typical etiologies of ANSD include prematurity, Cytomegalovirus (CMV), hyperbilirubinemia, anoxia, hypoxia, congenital brain anomalies, ototoxic drug exposure, and genetic factors ${ }^{5}$. Clinical evidence of ANSD can also be attributed to auditory nerve aplasia/dysplasia ${ }^{6,7}$.

The rehabilitation options for ANSD patients depend on the individual's hearing needs and the location of the pathologies. Hearing aids may not be an effective treatment due to the auditory synchronization issues associated with the postsynaptic disorder ${ }^{8}$. Several studies have established that cochlear implant $(\mathrm{CI})$ may be a good option for patients with $\mathrm{ANSD}^{8-10}$.

CAPOS (cerebellar ataxia, areflexia, pes cavus, optic atrophy, and sensorineural hearing loss) is a genetic syndrome that is classified as an ATP1 A3 gene mutation-related neurological disorder. The prognosis for CAPOS syndrome is progressive. It generally starts with the sudden onset of cerebellar ataxia and febrile illness. Recurrent episodes have also been reported ${ }^{11}$. Hearing loss is a common symptom in patients with CAPOS syndrome, however the nature and prognosis of the disease can vary. In CAPOS syndrome, mutations in the ATP1 A3 gene may cause auditory neuropathy that affect the postsynaptic site, resulting in a disruption in the synapses between the afferent auditory nerve and the inner hair cells ${ }^{12}$. This disruption is described as postsynaptic synaptopathy ${ }^{13}$. Auditory interventions can be confusing for subjects with ANSD, and an additional disorder, like CAPOS syndrome, furter complicates the course of interventions more markedly. Few studies on the benefits of Cls in subjects with ANSD and CAPOS syndrome have been reported in the literature. Therefore, this paper presents outcomes of $\mathrm{CI}$ in a rare case of ANSD with CAPOS syndrome.

\section{CASE REPORT}

Our case was 14 years old during our study, and she suffered from varicella disease when she was 8 years old. Sudden hearing loss occurred after this febrile illness, and she received treatment procedure for idiopathic sudden hearing loss at a different hospital. The patient did not receive any audiological interventions until she visited our clinic. She was referred to our clinic when she was 11 years old with complaints of dizziness and vision problems, as well as hearing loss and poor speech understanding performance in the presence of noise. Her audiometric evaluation when she was 11 years old (during her first visit) indicated moderate hearing loss with low-frequency sloping, as demonstrated by the audiogram in Figure 1.

Clear OAE responses were detected. ANSD was confirmed with an absent auditory brainstem response and presence of cochlear microphonics 


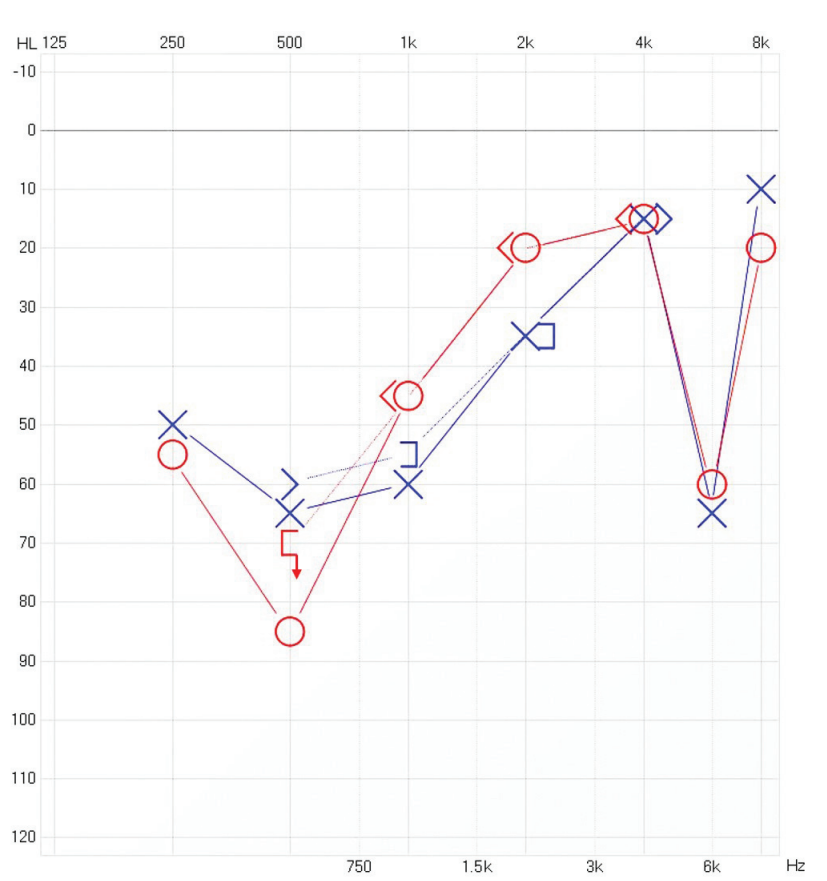

Figure 1. Behavioral pure-tone air conduction thresholds at 11 years old.

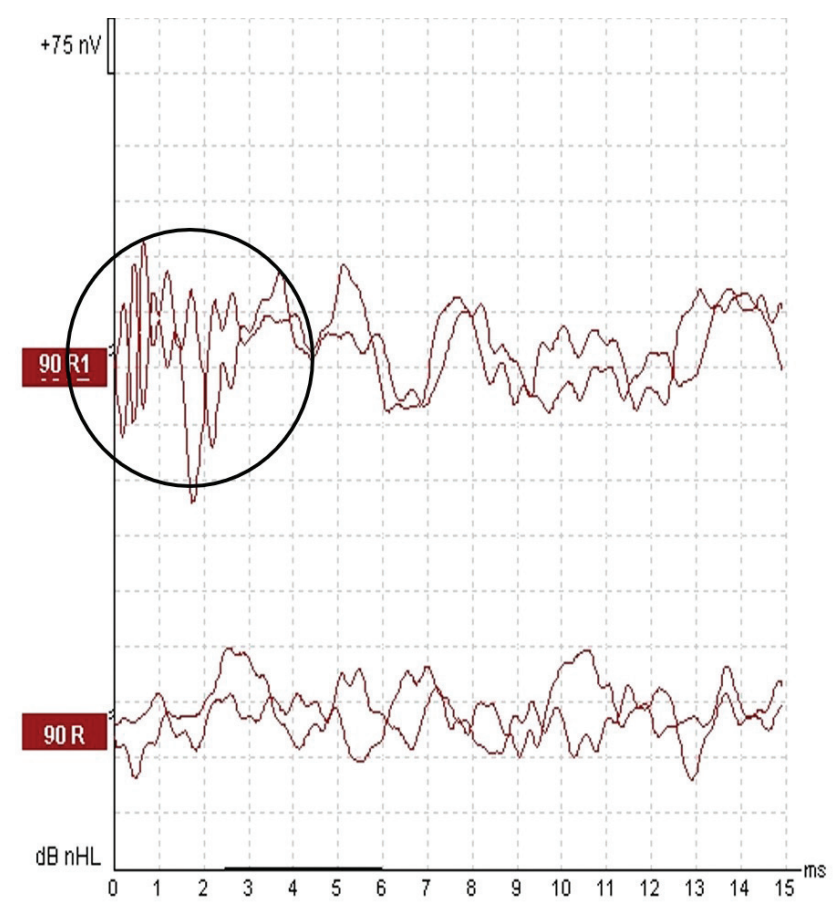

for both ears (Figure 2). ABR was performed during natural sleep using the Interacoustics Eclipse (Interacoustics, Middlefart, Denmark) with ER-3A insert earphones. The stimulus artifact was confirmed by performing a control trace, after removing the insert earphones, and preventing the sound from being delivered to the ear. The patient's audiological evaluations at 11 years old (during her first visit) are summarized in Table 1.

The patient's prognosis deteriorated in speech understanding, balance, and vision. After genetic testing, she was diagnosed with CAPOS syndrome. Corresponding ATP1A3 analysis revealed that she carried a heterozygous variant, c.2491 G > A: p.E831K of the ATP1A3 gene which is classified as 'pathogenic' by dbSNP and 'likely pathogenic' by the CLINVAR database (https://www. ncbi.nlm.nih.gov/clinvar/). This genetic variant was not detected in the patient's parents. Radiological evaluations confirmed that there were no cochlear and/or auditory nerve malformations.

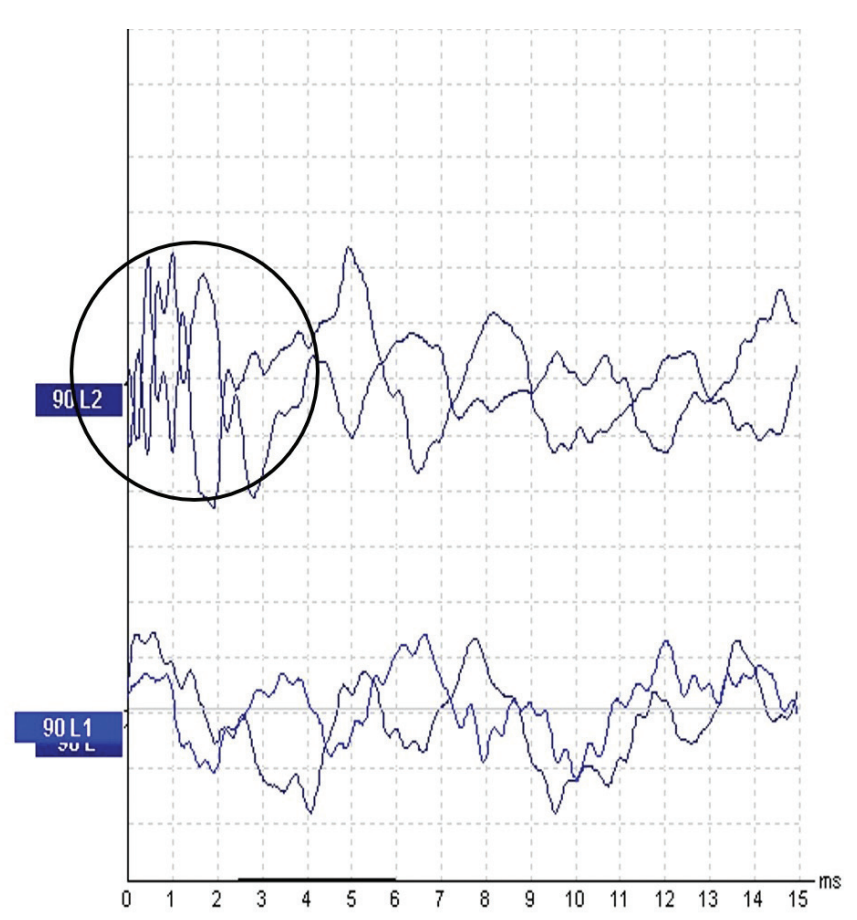

Figure 2: Click Evoked ABR result with rarefaction and condensation polarities for the patient. The upper part of the figure shows the cochlear microphonics which are indicated in the circle line. The lower part are the control traces (no stimulus presented to patient) for controlling any stimulus related artifact. 
Table 1. Audiological test results at 11 years old.

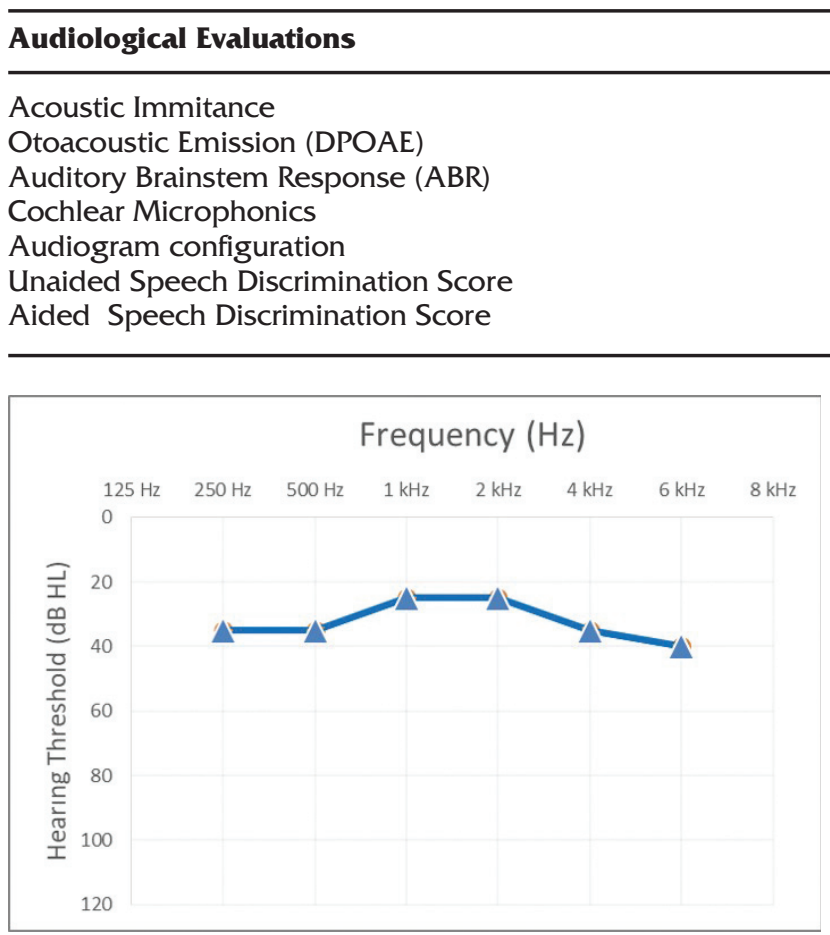

Figure 3. Behavioral frequency modulated tones thresholds with $\mathrm{CI}$ after one-year CI usage.

The patient briefly used bilateral a hearing aid equipped with frequency modulation (FM) system, but she rejected the device after complaints of poor speech perception abilities. Our speech perception evaluations also confirmed that she did not benefit from the hearing aids (Table 1). After her one-year follow-up, when she was 12 years old, she received a unilateral $\mathrm{CI}$ (Cochlear Nucleus CI 24RE) in the right ear. All the electrode impedance telemetry values were within a normal ranges. Electrical compound action potentials were detected for all electrodes using Neural Response Telemetry. Her Cl was adjusted to her behavioral threshold and comfort level. The patient was followed up regularly with free field pure-tone audiometry, and her behavioral pure tone thresholds were within the range of $20-40$ dB HL (Figure 3).

The speech audiometry was conducted using a mono-syllabic, phonetically balanced word discrimination test 14 in a sound-trated, double-

\section{Findings}

Normal tympanogram, acoustic reflexes absent for both ears

Present for both ears

No response for both ears

Present for both ears

Reverse sloping audiogram for both ears

$34 \%$ for right ear, $38 \%$ for the left ear

$28 \%$

walled room (IAC Acoustics, Sound Seal, IL, USA). Words were presented through loudspeakers that was positioned at $0^{\circ}$ azimuth and $0^{\circ}$ elevation and that were located $1-\mathrm{m}$ from the patient. She had clear speech during the tests. Her word discrimination score increased as the duration of $\mathrm{CI}$ usage increased (Figure 4). Her speech understanding in noise performance was tested with the Turkish Matrix Sentence Test ${ }^{15}$ and $50 \%$ speech reception threshold was reached at $7.4 \mathrm{~dB}$ SNR after oneyear of $\mathrm{CI}$ usage. Her test score was in the above to normal range for normal hearing ${ }^{15}$ but dropped to the normal range for $\mathrm{Cl}$ recipients, according to Hocberg et al. ${ }^{16}$.

The patient's music perception abilities were also evaluated using the Turkish version of the Clinical Assessment of Music Perception Test (T-CAMP) ${ }^{17}$ (for detailed information on the testing materials and procedure please see Kang et al. ${ }^{18}$ ). Testing was conducted in a free field with custom MATLAB (MathWorks Inc., Matick, MA, USA) pro- 
grams on a computer connected to a Madsen Astera Audiometer (Otometrics, Natus Medical, Denmark) with a sound field presentation level of $65 \mathrm{dBA}$. All stimuli were presented through a JBL Control One loudspeaker (JBL, Harman International, USA) that was positioned at $0^{\circ}$ azimuth and $0^{\circ}$ elevation and located 1 -m from the subject. The subject scored 2,41 semitones on a pitch direction discrimination subtest and scored $45.83 \%$ and $8.33 \%$ on timbre and melody recognition subtests, respectively.

\section{DISCUSSION}

In this paper, we documented a case of ANSD with CAPOS syndrome and our results suggest that after careful selection these patients can also benefit from $\mathrm{CI}$ as much as patients with SNHL.

There are only a few studies in the literature that evaluated patients with CAPOS syndrome and their $\mathrm{Cl}$ outcomes. Han et al. ${ }^{12}$ reported 3 cases confirmed with ATP1A3 mutations and two of them underwent $\mathrm{CI}$. They monitored speech performance for 6 months and the speech perception test scores improved as the duration of $\mathrm{Cl}$ usage increased. Tranebjærg et al. ${ }^{11}$ presented 18 patients with CAPOS syndrome who had hearing problems and they stated that 4 patients received $\mathrm{Cl}$ and two of them gained significant benefit from $\mathrm{CI}$. Patients who have gained significant benefit from $\mathrm{Cl}$ were younger than patients who have not. Considering the beneficial effects of $\mathrm{CI}$ in ANSD patients with disorders of inner hair cells, and the presence of synapses or the myelinated dendrites of spiral ganglion cells ${ }^{19}$, we can say that it is not surprising to observe beneficial effects of $\mathrm{Cl}$ in patients with ATP1A3 mutation -related ANSD. $\mathrm{CI}$ can bypass the site of lesion in these patients and present a clear and synchronized signal to the auditory nerve. Synchronization of the auditory nerve helps to improve speech perception as a result of improved temporal synchrony and spectral resolution. It is well known that temporal auditory processing is degraded in patients with
ANSD $^{20}$ and consistent stimulation of $\mathrm{Cl}$ electrodes can deliver the temporal envelope in each electrode, therefore improves the temporal synchrony ${ }^{21}$. Although some studies have suggested that patients with ANSD did not perform poorly in frequency discrimination test like they did in temporal processing tests ${ }^{22}$, it is still crucial to present spectrally rich information to the auditory nerve for good speech perception.

Contribution of temporal and spectral information in music perception is similar to speech perception. Broader spectral resolution with temporal information is crucial for good music perception. Our findings on the music perception is unique in the literature for ANSD patients with CAPOS syndrome. In previous studies $\mathrm{CI}$ users performed differently. Mean PDD scores ranged between $2.95^{21}$ and $4.6^{23}$ semitones, melody recognition scores between $10.61^{23,24}$ and $29.6^{23}$ and timbre recognition scores between $34.09^{23,24}$ and $48.2^{23}$.

Our patient's score on the timbre recognition test $(45.83 \%)$ was superior to that detected in a previous study (34.09\%) with similar study group ${ }^{24}$, possibly as a result of residual hearing capacity in high frequencies. Reverse sloping audiometric configuration is very common in patients with CAPOS syndrome and ANSD as reported in previous studies ${ }^{11,12,25}$. Although the contribution of residual hearing in case of ANSD is controversial, we can speculate that some benefit can still be achievable. Studies on the music perception abilities of $\mathrm{Cl}$ users showed that, while low frequency residual hearing is beneficial for pitch perception $^{26}$, timbre perception needs broader frequency perception especially in high frequencies. Timbre recognition performance of our patient might be the manifestation of the contribution of residual hearing in high frequencies. Scores observed in PDD and melody recognition subtest scores were similar to the scores obtained by the patients with sensorineural hearing loss in previous studies in this age range ${ }^{24}$, which can be a result of a similar low frequency hearing capacity in our case and in 
patients with severe/profound SNHL. Therefore, contribution of residual hearing in patients with ANSD should be considered.

Another consideration in case of CAPOS syndrome is the effect of optic atrophy and the possible deteriorations in the visual domain. Early diagnosis of the hearing loss and interventions with hearing aids and/or Cls have vital importance and can be life-changing for these patients. Prevention of sensory deprivation, especially in younger age, can confer lifelong benefit for patients with CAPOS syndrome.

\section{CONCLUSION}

We presented a patient who had ANSD with CAPOS syndrome that successfully received and benefited from $\mathrm{Cl}$. Audiological management of ANSD with CAPOS syndrome could be complicated as a result of complex nature of both disorders. After careful audiological follow-ups and detailed evaluations, patients should be considered as candidates for the implantation of cochlear implant.

\section{REFERENCES}

1. Berlin CI, Hood L, Morlet T, Rose K, Brashears S. Auditory neuropathy/dys-synchrony: diagnosis and management. Ment Retard Dev Disabil Res Rev. 2003;9:25-231. [CrossRef]

2. Berlin CI, Hood LJ, Morlet T, et al. Multi-site diagnosis and management of 260 patients with auditory neuropathy/ dys-synchrony (auditory neuropathy spectrum disorder. Int J Audiol. 2010;49:30-43. [CrossRef]

3. Zeng F-G, Kong Y, Michalewski HJ, Starr A. Perceptual consequences of disrupted auditory nerve activity. J Neurophysiol. 2005;93:3050-63. [CrossRef]

4. Rance G, Starr A. Pathophysiological mechanisms and functional hearing consequences of auditory neuropathy. Brain. 2015;138:3141-58. [CrossRef]

5. Rajput K, Saeed M, Ahmed J, et al. Findings from aetiological investigation of Auditory Neuropathy Spectrum Disorder in children referred to cochlear implant programs. Int J Pediatr Otorhinolaryngol. 2019;116:79-83. [CrossRef]

6. Buchman CA, Roush PA, Teagle HFB, Brown CJ, Zdanski CJ, Grose JH. Auditory Neuropathy Characteristics in Children with Cochlear Nerve Deficiency. Ear Hear. 2006;27:399-408. [CrossRef]

7. Atilgan A, Öztürk S, Bİnnetoğlu A. Cochlear Nerve Agenesis in Unilateral Auditory Neuropathy Spectrum Disorder: Case Report. Turkish J Audiol Hear Res. 2018:1-5.
8. Sharma A, Cardon G. Cortical development and neuroplasticity in Auditory Neuropathy Spectrum Disorder. Hear Res. 2015;330:221-32. [CrossRef]

9. Breneman A, Gifford RH, Dejong MD. Cochlear Implantation in Children with Auditory Neuropathy Spectrum Disorder: Long Term Outcomes. J Am Acad Audiol. 2012;23:5-17. [CrossRef]

10. Teagle HFB, Roush PA, Woodard JS, et al. Cochlear implantation in children with auditory neuropathy spectrum disorder. Ear Hear. 2010;31:325-35. [CrossRef]

11. Tranebjærg L, Strenzke N, Lindholm S, et al. The CAPOS mutation in ATP1A3 alters Na/K-ATPase function and results in auditory neuropathy which has implications for management. Hum Genet. 2018;137:111-27. [CrossRef]

12. Han K-H, Oh D-Y, Lee S, et al. ATP1A3 mutations can cause progressive auditory neuropathy: a new gene of auditory synaptopathy. Sci Rep. 2017;7:16504. [CrossRef]

13. Shearer AE, Hansen MR. Auditory synaptopathy, auditory neuropathy, and cochlear implantation. Laryngoscope Investig Otolaryngol. July 2019. [CrossRef]

14. Akşit M. Konuşmayı Ayırt Etme Testi için İzofonik Tek Heceli Kelime Listelerinin. Oluşturulması (Unpublished master's thesis). Marmara University Health Sciences Institute. 1994.

15. Zokoll MA, Fidan D, Türkyılmaz D, et al. Development and evaluation of the Turkish matrix sentence test. Int J Audiol. 2015;54(Suppl 2):51-61. [CrossRef]

16. Hochberg I, Boothroyd A, Weiss M, Hellman S. Effects of noise and noise suppression on speech perception by cochlear implant users. Ear Hear. 1992;13:263-71. http://www.ncbi. nlm.nih.gov/pubmed/1397769. Accessed August 5, 2019. [CrossRef]

17. Yüksel M. Relationship Between Spectral and Temporal Auditory Processing and Music Perception Abilities of Cochlear Implant Users (Unpublished master's thesis). Marmara University Health Sciences Institute, 2019.

18. Kang R, Nimmons GL, Drennan W, et al. Development and Validation of the University of Washington Clinical Assessment of Music Perception Test. Ear Hear. 2009;30:411-8. [CrossRef]

19. Santarelli R, Rossi R, Scimemi P, et al. OPA1-related auditory neuropathy: Site of lesion and outcome of cochlear implantation. Brain. 2015;138:563-76. [CrossRef]

20. Zeng F-G, Oba S, Garde S, Sininger Y, Starr A. Temporal and speech processing deficits in auditory neuropathy. Neuroreport. 1999; 10:3429-35. [CrossRef]

21. Drennan WR, Longnion JK, Ruffin C, Rubinstein JT. Discrimination of Schroeder-Phase Harmonic Complexes by Normal-Hearing and Cochlear-Implant Listeners. J Assoc Res Otolaryngol. 2008;9:138-49. [CrossRef]

22. Vinay, Moore BCJ. Ten(HL)-test results and psychophysical tuning curves for subjects with auditory neuropathy. Int J Audiol. 2007;46:39-46. [CrossRef]

23. Won JH, Drennan WR, Kang RS, Rubinstein JT. Psychoacoustic abilities associated with music perception in cochlear implant users. Ear Hear. 2010. [CrossRef]

24. Jung $\mathrm{KH}$, Won JH, Drennan WR, et al. Psychoacoustic Performance and Music and Speech Perception in Prelingually Deafened Children with Cochlear Implants. Audiol Neurotol. 2012;17:189-97. [CrossRef]

25. Paquay S, Wiame E, Deggouj N, et al. Childhood hearing loss is a key feature of CAPOS syndrome: A case report. Int J Pediatr Otorhinolaryngol. 2018;(September 2017):191-4. [CrossRef]

26. Gfeller KE, Olszewski C, Turner C, Gantz B, Oleson J. Music Perception with Cochlear Implants and Residual Hearing. Audiol Neurotol. 2006;11:12-5. [CrossRef] 